\title{
ON THE RELATIONSHIP OF RHODUSITE TO GLAUCOPHANE
}

\author{
By C. S. Pichamuthu \\ (Professor of Geology, University of Mysore, Central College, Bangalore) \\ Received October 30, 1944
}

RHoDUsire is a soda-amphibole which was first collected in 1889 by Bukowski $(1889,226)$ from Rhodus Island, Asia Minor. Specimens of this were sent by him to Baron Foullon for investigation. Foullon had the mineral analysed and he named it rhodusite $(1894,176)$. He considered the mineral to be a variety of glaucophane, and this early description has been followed more or less by later writers. Isküll $(1908,387)$ refers to it as an alumina-free ferric glaucophane. According to Murgoci $(1915,633)$, the mineral belongs to the extreme ferric end of the glaucophane series. Hintze $(1897,1260)$ has listed this mineral under glaucophane. So has Dana $(1911,46)$, and this has been repeated in Dana's Text-book revised by Ford $(1932,577)$, where rhodusite is stated to be a fibrous variety of glaucophane.

A consideration of the chemical and optical properties of rhodusite and glaucophane, however, reveal several points of difference. In Table I, the four existing analyses of rhodusite are given, together with four analyses of glaucophane published by Kunitz $(1930,244)$.

TABIE I

\begin{tabular}{|c|c|c|c|c|c|c|c|c|c|c|}
\hline & & & 1 & 2 & 3 & 4 & $\mathbf{A}$ & B & $\mathrm{C}$ & D \\
\hline $\begin{array}{l}\mathrm{SiO}_{2} \\
\mathrm{Al}_{2} \mathrm{O}_{3} \\
\mathrm{Fe}_{2} \mathrm{O}_{3} \\
\mathrm{FeO} \\
\mathrm{MgO} \\
\mathrm{CaO} \\
\mathrm{Na}_{2} \mathrm{O} \\
\mathrm{K}_{2} \mathrm{O} \\
\mathrm{H}_{2} \mathrm{O} \\
\mathrm{MnO}\end{array}$ & $\begin{array}{l}\because \\
\because \\
\because \\
\because \\
. \\
\because \\
\because \\
\because \\
\because\end{array}$ & $\begin{array}{c}\because \\
\because \\
\because \\
\because \\
\because \\
\because \\
\because \\
\cdots \\
\cdots \\
\cdots\end{array}$ & $\begin{array}{r}55.06 \\
0.49 \\
15 \cdot 48 \\
7.40 \\
11.49 \\
0.98 \\
6 \cdot 38 \\
0.80 \\
1.98 \\
\ldots\end{array}$ & $\begin{array}{r}54.01 \\
0.23 \\
15.70 \\
9.42 \\
10.01 \\
1.52 \\
6.22 \\
0.35 \\
2.25 \\
0.14\end{array}$ & $\begin{array}{r}54 \cdot 38 \\
0.28 \\
15 \cdot 12 \\
9.21 \\
10 \cdot 54 \\
1 \cdot 23 \\
6 \cdot 86 \\
0.31 \\
2 \cdot 16 \\
0 \cdot 11\end{array}$ & $\begin{array}{r}55.06 \\
0.18 \\
14.54 \\
7.17 \\
12.30 \\
1.17 \\
6.52 \\
0.23 \\
2.44 \\
0.09\end{array}$ & $\begin{array}{r}57.73 \\
12.04 \\
1.16 \\
5.41 \\
13.02 \\
1.04 \\
6.98 \\
0.68 \\
2.27 \\
. .\end{array}$ & $\begin{array}{r}56.97 \\
10 \cdot 83 \\
2.92 \\
8 \cdot 27 \\
10.43 \\
0.68 \\
6.79 \\
0.65 \\
2.23 \\
. .\end{array}$ & $\begin{array}{r}56 \cdot 77 \\
11 \cdot 28 \\
1 \cdot 89 \\
10 \cdot 84 \\
8 \cdot 92 \\
1 \cdot 24 \\
6 \cdot 45 \\
0 \cdot 60 \\
1.93 \\
. .\end{array}$ & $\begin{array}{r}55.47 \\
12.38 \\
1.62 \\
13.73 \\
7.36 \\
0.38 \\
6.70 \\
0.82 \\
2.01 \\
\ldots\end{array}$ \\
\hline & & & $100 \cdot 06$ & 99.85 & $100 \cdot 20$ & $99 \cdot 70$ & $100 \cdot 33$ & 99.77 & 99.92 & $100 \cdot 47$ \\
\hline
\end{tabular}

1. Rhodusite--H. B. Foullon, "Uber Gesteine und Minerale von der Insel Rhodus," Sitz. Math-natur. k.k. Akad. Wiss., 1894, 100, I Heft, Abt. I, 174.

2, 3, 4. Rhodusite.-W. Isküll, "Uber den Rhodusit vom Flusse Asskys (Bergbezirk Minussinsk in Sibirien). Beiträge zur Kenntnis seiner chemischen Constitution und Verwitterung," Zeits. Kryst., 1908, 44, 371-74.

A, B, C, D. Glaucophane.-Quoted from W. Kunitz, "Die Isomorphieverhältnisse in der Hornblendegruppe," Neues Jahrb. 1930, B. B. 60, Abt. A, 244. 
It will be seen from this table that rhodusite contains a very small percentage (less than 0.5 per cent.) of $\mathrm{Al}_{2} \mathrm{O}_{3}$, whereas in glaucophane it is very high (in analyses $\mathrm{A}$ and $\mathrm{D}$ it is over 12 per cent.). The other marked variation is in the $\mathrm{Fe}_{2} \mathrm{O}_{3}$ content; in rhodusite it is about 15 per cent. whereas in glaucophane it is very much less, rarely reaching 3 per cent; while in many glaucophanes this is less than 1 per cent. (Kunitz, 1930, 198). It does not seem quite satisfactory to get over these differences by merely designating rhodusite as an alumina-free ferric glaucophane.

These differences are also brought out clearly by calculating the number of metal atoms of each kind on a basis of $24(\mathrm{O}, \mathrm{OH}, \mathrm{F})$. In Table II, these calculations have been set out, and it will be seen from this that while there is close correspondence in the values for all the other atoms, $\mathrm{Al}$ and $\mathrm{Fe}^{\prime \prime \prime}$ show great differences.

TABLE II

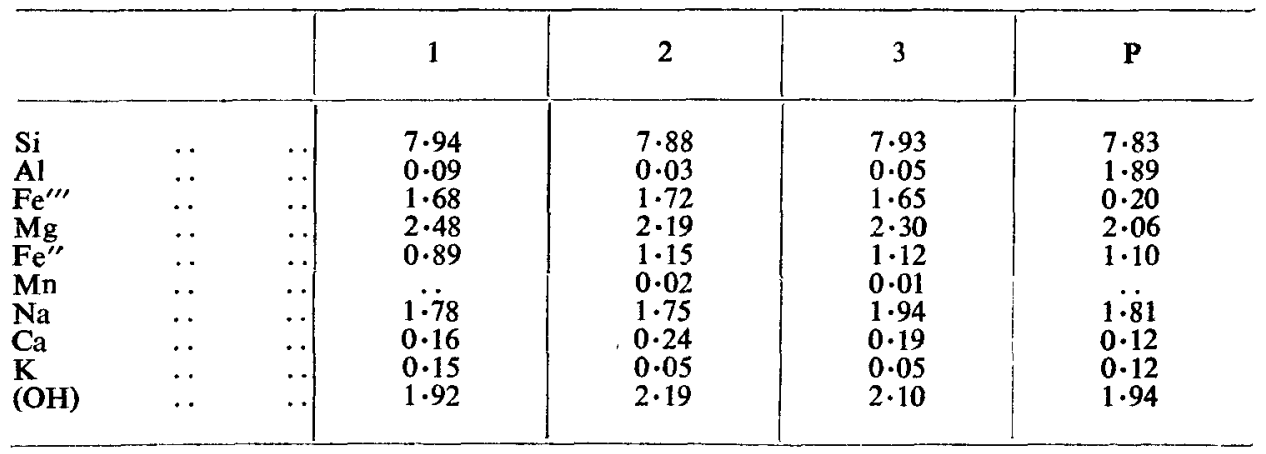

1, 2, 3. Rhodusite-C Correspond to the first three analyses given in Table $I$.

P. Glaucophane--Average of the four glaucophane analyses given in Table $\mathbf{I}$.

$\mathrm{Al}$ falls between the Si group and the $\mathrm{Mg}$ group and according to Warren $(1930,198)$ may be expected to replace either Si or $\mathrm{Mg}$. From Table II it is seen that in rhodusite $\mathrm{Al}$ and $\mathrm{Si}$ together form 8 atoms, whereas in glaucophane $\mathrm{Al}$ is in excess and replaces partly $\mathrm{Si}$ and partly $\mathrm{Mg}$.

In their study of the composition of the alkali amphiboles, Berman and Larsen $(1931,142$ ) have given the ratio of $\mathrm{Mg}: \mathrm{Al}: \mathrm{Si}$ in a triangular diagram on the assumption that the sum of these three is constant, any variation from the total of 13 being considered by them as due to experimental error. By noting the positions where the greatest concentration of analyses are found, these authors have determined the most common amphibole types. This diagram is reproduced in Fig. 1, and in it are plotted the position of the eight analyses given in Table I. It will be seen that while the glaucophane analyses correspond very nearly to the position given to 


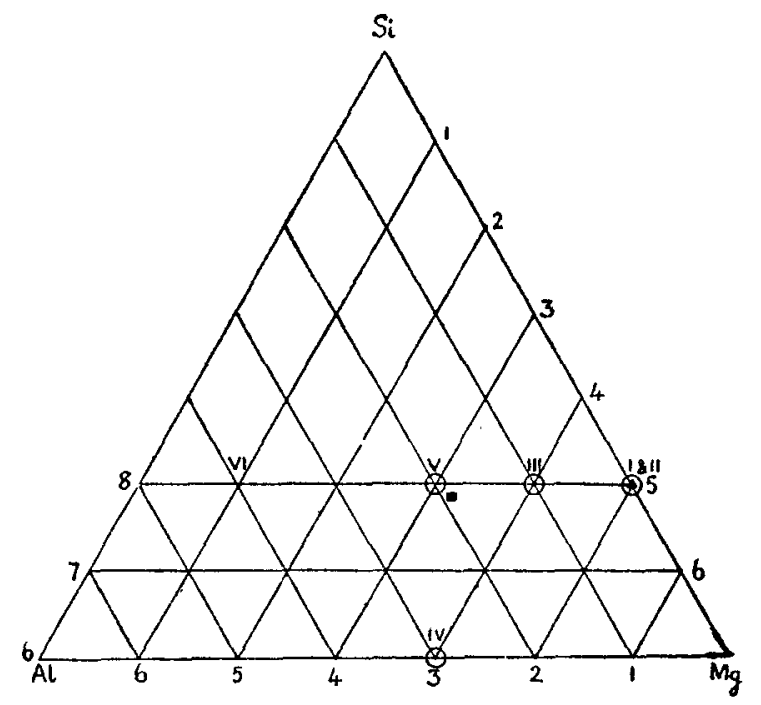

Fig. 1. Composition of the Amphiboles (after Berman and Larsen). Mg-Al-Si Ratios.

I. Tremolite, II. Soda-Tremolite, III. Arfvedsonite, IV. Hastingsite, V. Glaucophane types, VI. Glaucophane (?). The small inked square represents the position of the glaucophane analyses, and the small inked triangle, the position of the rhodusite analyses given in Table $I$.

the glaucophane types by Berman and Larsen, the rhodusite analyses occupy a different position.

When the optical properties of rhodusite and glaucophane are compared, the differences between these minerals become still more apparent.

In the case of rhodusite there appears to be some contradiction between the descriptions of Isküll and Murgoci. Isküll $(1908,373-74)$ states that in the first two analysed specimens of rhodusite, the optic sign is negative, and the extinction not $Z \wedge \mathrm{c}$, whereas according to him, the optic sign of the third specimen may be positive or negative. According to Murgoci $(1915,632)$, the sign of the mineral appears to be positive, and his statement that the sign of elongation of rhodusite is positive is followed by a question mark, for he thinks that he might have made a mistake in this determination. In a later paper, Murgoci $(1922,426)$ states that the sign of the mineral is negative. Niggli $(1926,473)$ gives the optic plane and $Z$ as perpendicular to 010 and the angle of extinction as $X \wedge c$. The optic orientation of this mineral is also diagrammatically represented in Fig. 216 of Niggli's Mineralogy (1926, 471).

Glaucophane has its optic plane parallel to 010 , the extinction is $Z, \wedge c$, the sign of the mineral is negative, and the sign of elongation positive. It 
is clear from this that the optic orientation of glaucophane is quite different from that of rhodusite.

Rhodusite cannot, therefore, be considered as a variety of glaucophane, because both in chemical composition as well as in optical characters there are fundamental differences between the two minerals.

\section{REFERENCES}

Berman, H., and Larsen, E. S. . "Composition of the alkali amphiboles," Amer. Miner., 1931, 16.

Bukowski, G.

.. " Grundzüge des geologischen Baues der Insel Rhodus," Sitz. Math. Naturw. Cl. Akad. Wiss., 1889, 98, Abt. I.

Dana, E. S.

. A A System of Mineralogy, Second Appendix, 1911, New York. and Ford, W. E.

.. A Text-book of Mineralogy, Fourth Edition, 1932, New York.

Foullon, H. B.

.. "Uber Gesteine und Minerale von der Insel Rhodus," Sitz. Math. Naturw. k.k. Akad. Wiss., 1894, 100, Heft I, Abt. I.

Hintze, C.

.. Handbuch der Mineralogie, 1897, Band II, Leipzig.

Isküll, W.

.. "Uber den Rhodusit vom Flusse Asskys (Bergbezirk Minussinsk in Sibirien). Beiträge zur Kenntnis seiner chemischen Constitution und Verwitterung," Zeits. Kryst., 1908, 44.

Kunitz, w.

.. "Die Isomorphieverhāltnisse in der Hornblendegruppe," Neues Jahrb., 1930, B.B. 60, Abt. A.

Murgoci, G.

.. "Sur la rhodusite et l'abriachanite," Comp. Rend. Acad. Sci., 1915, 160.

.. "Sur la classification des amphiboles bleues et de certaines hornblendes," ibid., 1922, 175.

Niggli, P.

.. Lehrbuch der Mineralogie, II. Spezielle Mineralogie, Zweite auflage, Berlin, 1926.

Warren, B. E.

.. "The Crystal Structure and Chemical Composition of the Monoclinic Amphiboles," Zeits. Kryst., 1930, 72. 